\title{
Are Hematological Parameters Useful in Assessing Disease Activity in Chronic Otitis Media?
}

\author{
Kronik Otitis Mediada Hastalık Aktivitesinin Değerlendirilmesinde Hematolojik \\ Parametreler Yararlı mıdır?
}

\author{
(1) Fazilet Altın, (1) Yalçın Alimoğlu
}

University of Health Sciences, Haseki Training and Research Hospital, Clinic of Otolaryngology, Istanbul, Turkey

\section{Abstract}

Aim: To investigate the role of hematological parameters in assessing disease activity of chronic otitis media (COM).

Methods: Patients who underwent surgery for COM between 2014 and 2018 were examined retrospectively. The patients were divided into active and inactive COM groups. Active group was divided into cholesteatoma, granulation tissue, and cholesteatoma + granulation tissue subgroups. Inactive group was divided into tympanosclerosis and normal middle ear mucosa subgroups. Preoperative complete blood count parameters were examined retrospectively. Neutrophil-to-lymphocyte ratio (NLR), platelet-to-lymphocyte ratio (PLR) and mean platelet volume (MPV) in active and inactive groups and also the values in subgroups of each group were compared.

Results: Our study contained 1126 patients. There were 558 (49.55\%) male, 568 (50.45\%) female patients. The mean age was $31 \pm 14.93$ (7-74) years. Active and inactive groups consisted of 329 (29.22\%) and 797 (70.78\%) patients, respectively. There was no significant difference between active and inactive COM groups in terms of NLR $(p=0.234), \operatorname{PLR}(p=0.733)$ and MPV $(p=0.992)$. There was no significant difference among subgroups of active and inactive groups $(p>0.05)$. Receiver operating characteristic curve analysis for NLR, PLR and MPV in the groups revealed no cut-off value for differentiating any group from another ( $p>0.05)$.

Conclusion: NLR, PLR, and MPV values do not have any significant value in the assessment of disease activity of COM.

Keywords: Chronic otitis media, disease activity, hematological parameter

\section{Öz}

\begin{abstract}
Amaç: Kronik otitis media'nın hastalık aktivitesinin değerlendirilmesinde hematolojik parametrelerin rolünü araştırmak.
\end{abstract}

Yöntemler: 2014-2018 yılları arasında kronik otitis media nedeniyle cerrahi tedavi uygulanan olgular geriye yönelik olarak incelenmiştir. Olgular aktif ve inaktif otitis media gruplarına ayrılmıştır. Aktif kronik otitis media; kolesteatoma, granülasyon dokusu ve kolesteatoma + granülasyon dokusu alt gruplarına ayrılmıştır. Inaktif kronik otitis media timpanoskleroz ve normal orta kulak mukozası alt gruplarına ayrılmıştır. Preoperatif tam kan sayımı parametreleri geriye yönelik incelenmiştir. Aktif ve inaktif kronik otitis media grupları ve her bir grubun alt gruplarının nötrofil/lenfosit oranı, trombosit/lenfosit oranı ve ortalama trombosit hacmi karşılaştırılmıştır.

Bulgular: Çalışmamı 1126 hastayı içermektedir. Beş yüz elli sekiz $(\% 49,5)$ erkek, $568(\% 50,45)$ kadın hasta vardı. Ortalama yaş $31 \pm 14,93$ (7-74) yıl idi. Aktif kronik otitis media 329 (\%29,22), inaktif kronik otitis media $797(\% 70,87)$ hastayı içeriyordu. Aktif ve inaktif kronik otitis media grupları arasında nötrofil/lökosit oranı $(p=0,234)$, trombosit/lenfosit oranı $(p=0,733)$ ve ortalama trombosit hacmi $(p=0,992)$ açısından istatistiksel olarak anlamlı fark yoktu. Aktif ve inaktif kronik otitis media'nın alt grupları arasında anlamlı fark yoktu $(p>0,05)$. Nötrofil/lenfosit oranı, trombosit/lenfosit oranı ve ortalama trombosit hacmi için alıcı işletim karakteristiği eğrisi analizi ile bir grubu diğerinden ayırmak için bir cut-off değeri bulunmamıştır $(p>0,05)$.

Sonuç: Nötrofil/lenfosit oranı, trombosit/lenfosit oranı ve ortalama trombosit hacminin kronik otitis media'nın hastalık aktivitesini değerlendirmek için tanısal bir önemi yoktur.

Anahtar Sözcükler: Kronik otitis media, hastalık aktivitesi, hematolojik parametre
Address for Correspondence/Yazışma Adresi: Yalçın Alimoğlu, University of Health Sciences, Haseki Training and Research Hospital, Clinic of Otorhinolaryngology, ìstanbul, Turkey Phone: +90 2125294400 E-mail: alimoglu2001@gmail.com ORCID: orcid.org/0000-0002-8823-6354 Received/Geliş Tarihi: 14 September 2019 Accepted/Kabul Tarihi: 02 November 2019

This study was presented in the $40^{\text {th }}$ Turkish National Congress of Otorhinolaryngology and Head \& Neck Surgery as an oral presentation in 2019.
${ }^{-}$Copyright 2020 by The Medical Bulletin of istanbul Haseki Training and Research Hospital The Medical Bulletin of Haseki published by Galenos Yayınevi. •Telif Hakkı 2020 istanbul Haseki Eğitim ve Araştırma Hastanesi Haseki Tıp Bülteni, Galenos Yayınevi tarafindan yayınlanmıştır. 


\section{Introduction}

Chronic otitis media (COM) is inflammation of the temporal bone air spaces accompanied by tympanic membrane perforation that lasts longer than 3 months (1). The etiology of COM is still not clear despite many suggested pathophysiological mechanisms. Oxidative stress and inflammation have been reported to play an important role $(1,2)$. Chronic infection can result in primary membrane perforation, granulation tissue formation, sclerosis, ossicular chain disruption and cholesteatoma. Surgical management is guided by clinical picture and includes simple primary myringoplasty, ossicular reconstruction and also mastoidectomy (3). Revision surgery may be required in some patients due to failure of primary surgery (4).

Hematological and biochemical biomarkers are commonly used to examine systemic response to inflammation. Many of these are time consuming and expensive tests but the hematological parameters such as the neutrophil-to-lymphocyte ratio (NLR), platelet-tolymphocyte ratio (PLR) and mean platelet volume (MPV) are more readily available and cheaper $(5,6)$.

Considering the differences in clinical presentations of COM, biomarkers may provide an advantage in surgical planning and patient counseling. In our study, we planned to investigate the diagnostic significance of the NLR, PLR and MPV values in the evaluation of disease activity in COM patients and to investigate if inflammation in COM has systemic reflections. To our knowledge, it is the first study with a large group of patients.

\section{Methods}

Patients who were scheduled for surgical management due to COM between 2014 and 2018 in our institute were examined retrospectively. Patients whose complete blood count results were available were included. Patients with diseases causing active inflammation, chronic lung and kidney diseases, hematological and cardiovascular diseases, neuromuscular disease, malnourishment, and patients with complications due to COM were excluded.

The patients were divided into two major groups as active and inactive COM by examining the patient files including microscopic ear examination and operative reports. Patients who had granulation tissue or cholesteatomas were categorized as active COM. Active COM patients were subgrouped into cholesteatoma, granulation tissue, and both cholesteatoma and granulation tissue groups; inactive COM were subdivided into normal middle ear mucosa and tympanosclerosis groups (Figure 1).

Preoperative complete blood count analyses were performed automatically with Sysmex XN-3000 (Kobe, Japan). Neutrophil, lymphocyte, platelet and MPV values were recorded from preoperative complete blood count results of each patient. NLR was calculated by dividing neutrophil count by lymphocyte count and PLR was calculated by dividing platelet count by lymphocyte count.

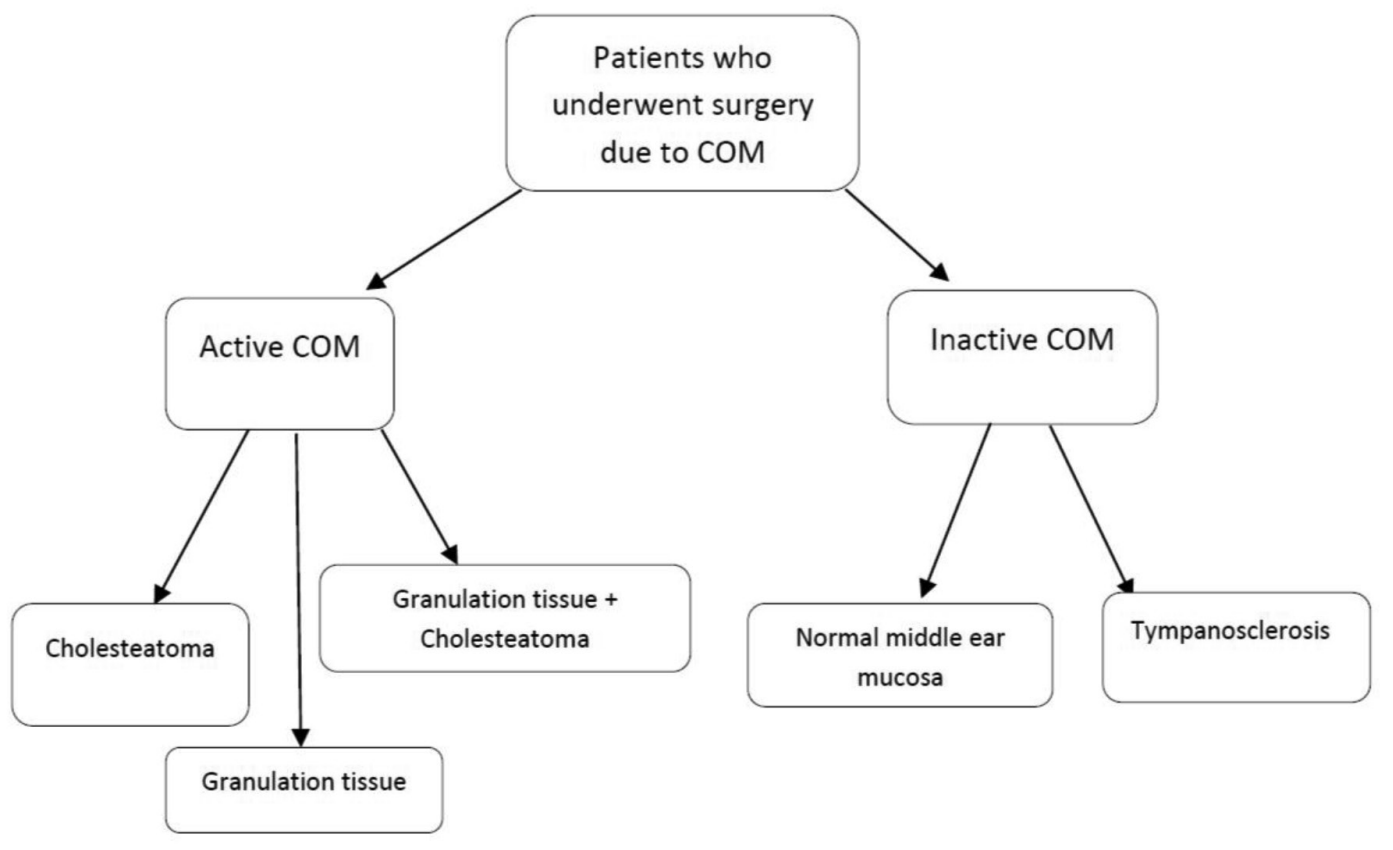

Figure 1. Groups of patients with COM

COM: Chronic otitis media 
NLR, PLR and MPV values were compared between active and inactive COM groups. Afterwards, NLR, PLR and MPV values were compared between the subgroups.

The study was conducted after obtaining approval from the Local Ethics Committee of Medical Speciality Training Board (TUEK) (approval no: 27R/2018). Our study was conducted in accordance with the principles of the Helsinki declaration.

\section{Results}

A total of 1126 patients were included. The mean age of the patients was $31 \pm 14.93$ (7-74) years. There were 558 male (49.55\%) and 568 female (50.45\%) patients. The NLR, PLR and MPV values in active and inactive COM patients are shown in Table 1.

There was no statistically significant difference in NLR $(Z=-1.19, p=0.234), P L R(Z=-0.341, p=0.733)$ and MPV values $(Z=-0.010, p=0.992)$ between active and inactive COM patients. There was no statistically significant differences in NLR ( $p=0.901), \operatorname{PLR}(p=0.556)$ and MPV values $(p=0.866)$ between granulation tissue, cholesteatoma and granulation tissue + cholesteatoma subgroups. There were no statistically significant differences in NLR $(p=0.440)$, PLR ( $p=0.379)$ and MPV values ( $p=0.637$ ) between normal middle ear mucosa and tympanosclerosis subgroups. NLR, PLR and MPV in the groups were evaluated by receiver operating characteristic curve analysis and no cut-off value was found $(p>0.05)$.

\section{Discussion}

Chronic otitis media is chronic inflammation of the tympanic cavity, mastoid air cells and mucosa extending to the inner surface of the eustachian tube lasting more than 3 months (1). Although tympanic membrane perforation and conductive hearing loss are almost always present, clinical presentation may vary. There is only tympanic perforation in some patients, while in others, there may be ossicular chain disruption, sclerosis, granulation tissue

\begin{tabular}{|l|l|l|l|}
\hline $\begin{array}{l}\text { Table 1. NLR, PLR and MPV values of active and inactive COM } \\
\text { patients }\end{array}$ \\
\hline & $\begin{array}{l}\text { Active COM } \\
\text { Mean } \pm \text { SD } \\
\text { (min-max) } \\
(\mathbf{n}=329)\end{array}$ & $\begin{array}{l}\text { Inactive COM } \\
\text { Mean } \pm \text { SD } \\
(\text { min-max) } \\
(\mathbf{n}=797)\end{array}$ & p \\
\hline NLR & $\begin{array}{l}2.08 \pm 1.38 \\
(0.00-13.46)\end{array}$ & $\begin{array}{l}1.95 \pm 1.16 \\
(0.48-22.40)\end{array}$ & 0.234 \\
\hline PLR & $\begin{array}{l}117.33 \pm 42.66 \\
(22.78-402.78)\end{array}$ & $\begin{array}{l}118.88 \pm 43.26 \\
(8.28-522.64)\end{array}$ & 0.733 \\
\hline MPV & $10.14 \pm 1.22$ & $\begin{array}{l}10.27 \pm 3.41 \\
(1.30-101.0)\end{array}$ & 0.992 \\
\hline & $(1.90-9.4)$ & &
\end{tabular}

NLR: Neutrophil-to-lymphocyte ratio, PLR: Platelet-to-lymphocyte ratio, MPV: Mean platelet volume, COM: Chronic otitis media, SD: Standard deviation, min: Minimum, max: Maximum, n: Number or chronic destructive keratinizing squamous epithelium, cholesteatoma. Many mechanisms have been implicated for bone resorption. These include chronic osteomyelitis, osteoclastic and osteolytic osteolysis, pressure necrosis, dissolution through enzymes, such as collagenase, acid phosphatase and lysozyme, local pH changes and vascular proliferation $(2,7)$.

There are many laboratory tests used to demonstrate systemic inflammation and many of these are timeconsuming and expensive. Recently, search for cheaper and easily applicable infection biomarkers including NLR, PLR and MPV have become popular. These parameters, which are readily available from complete blood count, have been investigated in many vascular, cardiac, rheumatologic and oncological diseases to be found to have prognostic value in some conditions (8-14).

The NLR has been examined in many otolaryngological conditions. Ulusoy et al. (15) examined NLR in tinnitus and found no significant difference between tinnitus patients and control group. However, Ozbay et al. (16) claimed that NLR could be used as a potential clinical marker in tinnitus patients. Ozbay et al. (17) also studied NLR in vertigo patients and they showed an increased NLR in patients when compared with control subjects. Bucak et al. (18) stated that the NLR can be used as a predictive marker in Bell's paralysis. Yenigun (19) showed that NLR might be beneficial in determining necessity and timing of surgery in patients with chronic tonsillitis. He also suggested that by using NLR, unnecessary surgery could be avoided. It has also been shown that NLR could be used as a predictive marker in the patients with obstructive sleep apnea and nasal polyposis $(20,21)$. High NLR has been shown to indicate poor prognosis in patients with sudden hearing loss $(22,23)$. Atan et al. (24) investigated the relationship between NLR and pediatric chronic serous otitis media. They suggested that NLR could be used as a diagnostic parameter. However, in studies performed in COM patients, NLR has not been shown to be a useful biomarker for evaluating clinical findings or complications (25-28). Similarly, in our study, we examined the NLR in a very large group of patients with COM. In our study of 1126 patients, we reached the conclusion that NLR has no diagnostic value for clinical evaluation of COM patients.

Other parameters suggested as an inflammation indicator are PLR and MPV $(28,29)$. PLR has also been used frequently as an indicator of inflammation in many studies. Ulusoy et al. (15) studied PLR in tinnitus patients and they found no difference when compared to the control group. On the other hand, Atan et al. (24) claimed that PLR can be used as diagnostic parameter for pediatric chronic serous otitis media. An increased MPV value has been 
linked to severe nasal septal deviation (30) and obstructive sleep apnea (31). Somuk et al. (32) also stated that MPV value was a helpful diagnostic parameter in pediatric chronic serous otitis media. Eryilmaz and Derin (28) found that the NLR was not diagnostic in pediatric patients with cholesteatoma but MPV values were lower in patients with cholesteatoma compared to control subjects. Therefore, they suggested that low MPV values in pediatric patients could be used as a parameter to predict cholesteatoma. In contrast, Yigit et al. (25) reported that neither MPV value nor NLR in patients with cholesteatoma had a value in predicting prognosis and accompanying bone destruction in patients with COM. Similarly, in our study, we found no statistically significant difference in both PLR and MPV when the groups and subgroups were compared.

Eryilmaz and Derin (28) suggested a cut-off value for MPV for detecting cholesteatoma. We attempted to establish such a value in our groups and subgroups but none could be found.

To the best of our knowledge, our study is the first largescale study. Our study can be criticized for its retrospective design. However, it reflects our 5-year experience in a large group of patients. NLR, PLR and MPV had no role in determining disease activity in COM patients.

\section{Conclusion}

COM is a common condition in the otolaryngology practice. Although they are easily available, NLR, PLR and MPV do not have any diagnostic value in clinical evaluation of active and inactive COM patients.

\section{Authorship Contributions}

Concept: F.A. Design: Y.A., F.A. Data Collection or Processing: F.A., Y.A. Analysis or Interpretation: Y.A., F.A. Literature Search: F.A. Writing: F.A., Y.A.

Conflict of Interest: No conflict of interest was declared by the authors.

Financial Disclosure: The authors declared that this study received no financial support.

\section{References}

1. Yilmaz T, Kocan EG, Besler HT, Yilmaz G, Gursel B. The role of oxidants and antioxidants in otitis media with effusion in children. Otolaryngol Head Neck Surg 2004; 131: 797-803.

2. Garca MF, Aslan M, Tuna B, Kozan A, Cankaya H. Serum myeloperoxidase activity, total antioxidant capacity and nitric oxide levels in patients with chronic otitis media. J Membrane Biol 2013;246:519-24.

3. Westerberg J, Harder H, Magnuson B, Westerberg L, Hydén D. Ten-year myringoplasty series: does the cause of perforation affect the success rate? J Laryngol Otol 2011;125:126-32.

4. Kaylie DM, Gardner EK, Jackson CG. Revision chronic ear surgery. Otolaryngol Head Neck Surg 2006;134:443-50.
5. Roxburgh CS, McMillan DC. Role of systemic inflammatory response in predicting survival in patients with primary operable cancer. Future Oncol 2010;6:149-63.

6. Gasparyan AY, Ayvazyan L, Mikhailidis DP, Kitas GD. Mean Platelet Volume: A Link Between Thrombosis and Inflammation? Curr Pharm Des 2011;17:47-58.

7. Kurihara A, Toshima M, Yuasa R, Takasaka T. Bone destruction mechanisms in chronic otitis media with cholesteatoma: specific production by cholesteatoma tissue in culture of bone-resorbing activity attributable to interleukin-1 alpha. Ann OtolRhinol Laryngol 1991;100:989-98.

8. Tuncel T, Uysal P, Hocaoglu AB, Erge DO, Karaman O, Uzuner $\mathrm{N}$. Change of mean platelet volume values in asthmatic children as an inflammatory marker. Allergol Immunopathol (Madr) 2012;40:104-7.

9. Mimidis K, Papadopoulos V, Kotsianidis J, et al. Alterations of platelet function, number and indexes during acute pancreatitis. Pancreatology 2004;4:22-7.

10. Núñez J, Núñez $E$, Bodí $V$, et al. Usefulness of the neutrophil to lymphocyte ratio in predicting long-term mortality in ST segment elevation myocardial infarction. Am J Cardiol 2008;101:747-52.

11. Duffy BK, Gurm HS, Rajagopal V, Gupta R, Ellis SG, Bhatt DL. Usefulness of an elevated neutrophil to lymphocyte ratio in predicting long-term mortality after percutaneous coronary intervention. Am J Cardiol 2006;97:993-6.

12. Cedrés $S$, Torrejon $D$, Martínez A, et al. Neutrophil to lymphocyte ratio (NLR) as an indicator of poor prognosis in stage IV non-small cell lung cancer. Clin Transl Oncol 2012;14:864-9.

13. Vizioli L, Muscari S, Muscari A. The relationship of mean platelet volume with the risk and prognosis of cardiovascular diseases. Int J Clin Pract 2009;63:1509-15.

14. Zahorec R. Ratio of neutrophil to lymphocyte counts-rapid and simple parameter of systemic inflammation and stress in critically ill. Bratisl Lek Listy 2001;102:5-14.

15. Ulusoy B, Bozdemir K, Akyol M, Mişe HI, Kutluhan A, Korkmaz $\mathrm{MH}$. Investigation of neutrophil-to-lymphocyte ratio, plateletto-lymphocyte ratio and mean platelet volume in patients with tinnitus. J Laryngol Otol 2018;132:129-32.

16. Ozbay I, Kahraman C, Balikci HH, et al. Neutrophil-tolymphocyte ratio in patients with severe tinnitus: prospective, controlled clinical study. J Laryngol Otol 2015;129:544-7.

17. Ozbay I, Kahraman C, Balikci HH, et al. Neutrophil-to-lymphocyte ratio in patients with peripheral vertigo: a prospective controlled clinical study. Am J Otolaryngol 2014;35:699-702.

18. Bucak A, Ulu S, Oruc $S$, et al. Neutrophil-to-lymphocyte ratio as a novel-potential marker for predicting prognosis of Bell palsy. Laryngoscope 2014;124:1678-81.

19. Yenigun A. The efficacy of tonsillectomy in chronic tonsillitis patients as demonstrated by the neutrophil-to-lymphocyte ratio. J Laryngol Otol 2015;129:386-91. 
20. Koseoglu S, Ozcan KM, Ikinciogullari A, Cetin MA, Yildirim E, Dere H. Relationship Between Neutrophil to Lymphocyte Ratio, Platelet to Lymphocyte Ratio and Obstructive Sleep Apnea Syndrome. Adv Clin Exp Med 2015;24:623-7.

21. Atan D, Özcan KM, Köseoğlu S, et al. New predictive parameters of nasal polyposis: neutrophil to lymphocyte ratio and platelet to lymphocyte ratio. Kulak Burun Bogaz Ihtis Derg 2015;25:97-101.

22. Ulu S, Ulu MS, Bucak A, Ahsen A, Yucedag F, Aycicek A. Neutrophil-to-lymphocyte ratio as a new, quick, and reliable indicator for predicting diagnosis and prognosis of idiopathic sudden sensorineural hearing loss. Otol Neurotol 2013;34:1400-4.

23. Özler GS. Increased neutrophil-lymphocyte ratio in patients with idiopathic sudden sensorineural hearing loss. J Craniofac Surg 2014;25:260-3.

24. Atan D, Apaydın E, Özcan KM, Dere H. New diagnostic indicators in chronic otitis media with effusion: neutrophil to lymphocyte ratio and thrombocyte lymphocyte ratio. ENT Updates 2016;6:12-5.

25. Yigit E, Celebi OO, Server EA, Longur ES. Neutrophile-toLymphocyte Ratio and Mean Platelet Volume in Chronic Otitis Media with or without Cholesteatoma. Istanbul Med J 2018;19:e162-6.

26. Kılıckaya MM, Aynali G, Tuz M, Bagcl O. Is There A Systemic Inflammatory Effect of Cholesteatoma? Int Arch Otorhinolaryngol 2017;21:42-5
27. Tansuker HD, Eroğlu S, Yenigün A, Taşkin Ü, Oktay MF. Can Serum Neutrophil-to-Lymphocyte Ratio Be a Predictive Biomarker to Help Differentiate Active Chronic Otitis Media From Inactive Chronic Otitis Media? J Craniofac Surg 2017;28:e260-3.

28. Eryilmaz MA, Derin S. Mean Platelet Volume as a Potential Predictor of Cholesteatoma in Children. J Craniofac Surg 2016;27:e575-8.

29. Gasparyan AY, Ayvazyan L, Mikhailidis DP, Kitas GD. Mean Platelet Volume: A Link Between Thrombosis and Inflammation? Curr Pharm Des 2011;17:47-58.

30. Unlu I, Kesici GG, Onec B, Yaman H, Guclu E. The effect of duration of nasal obstruction on mean platelet volume in patients with marked nasal septal deviation. Eur Arch Otorhinolaryngol 2016;273:401-5.

31. Rahangdale $S$, Yeh SY, Novack $V$, et al. The influence of intermittent hypoxemia on platelet activation in obese patients with obstructive sleep apnea. J Clin Sleep Med 2011;7:172-8

32. Somuk BT, Soyalıç $H$, Koc S, Gürbüzler L, Doğru S, Eyibilen A. Mean platelet volume as an inflammatory marker of chronic otitis media with effusion. Int J Pediatr Otorhinolaryngol 2014;78:1958-60. 